Academic Platform Journal of Engineering and Science

\title{
Demiryolu Akslarının Ultrasonik Muayene Yöntemi ve Phased Array Yöntemi ile Tahribatsız Muayenesi
}

\author{
${ }^{1}$ Yıldız Yaralı Özbek, ${ }^{2}$ Serhan Emre
}

\begin{abstract}
${ }^{1}$ Sakarya Üniversitesi, Mühendislik Fakültesi, Metalurji ve Malzeme Mühendisliği, Sakarya, yyarali@ sakarya.edu.tr, ${ }^{2}$ Türkiye Vagon Fabrikaları Müdürlüğü, Sakarya (TÜVASAŞ),
\end{abstract}

Araştırma Makales

Geliş Tarihi: 06.06.2018

Kabul Tarihi: 15.03 .2019

$\ddot{O} z$

Demiryolu taşımacılığının güvenlik felsefesi açısından, dinamik yük altında çalışan aksların düzenli muayenesinde hasara yol açacak korozyon çukurları ve yorulma çatlaklarının tespiti çok önemlidir. Alınması gereken kalite kontrol önlemleri, düzenli tahribatsız test kontrol yöntemleri ile güvenlik seviyesi geliştirilmeye çalışılmaktadır. Bu çalışmada demiryolu akslarının ultrasonik testi için gelişmiş ultrasonik muayene yöntemi olan Phased array yönteminin konvensiyonel ultrasonik muayene yöntemine karşı avantajları nicel olarak incelenmiştir.

Anahtar Kelimeler: demiryolu, aks, ultrasonik, phased, tahribatsız

\section{Using Conventional Ultrasonic Testing and Phased Array Method for Nondestructive Testing of Railway Axles}

${ }^{1}$ Yıldız Yaralı Özbek, ${ }^{2}$ Serhan Emre

${ }^{1}$ Sakarya University, Metallurgy and Materials Engineering Faculty, Sakarya, yyarali@sakarya.edu.tr

${ }^{2}$ Turkey Wagon Factory, Sakarya (TÜVASAŞ)

\begin{abstract}
For the safety assessment of railway transportation with regular inspection of the axles working underdynamic loads, detection of corrosion pits and fatigue cracks which lead to damage is important. Quality control measures should be taken, with regular non-destructive testing methods are being developed safety level. In this study, the advantages of phased array method which is for advanced ultrasonic test of railway axles over conventional ultrasonic test method quantitively.
\end{abstract}

Keywords: railway, axle, ultrasonic, phased, nondectructive

\section{GİRIŞ}

Ülkemizde hat iyileştirme ve yeni hat inşaatı ile hızlı tren işletmeciliğine geçilmektedir. Güvenilir kullanım şüphesiz her işletmenin hedeflerinin başında gelir. Güvenilir işletimin şartları ise uygun mamulün (ray, araç) tedarik edilmesi, montaj kalitesinin temini ve işletim sırasında vasıflı personel ve uygun teçhizatla bakım ve bu kapsamda tedarik ve işletimde ray ve araçlarda gerekli tahribatsız muayene faaliyetlerinin gerçekleştirilmesidir.

Yeni ve iyileştirilmiş tahribatsız muayene denetim methodları aksların güvenli hizmet şartlarını garantilemek için kullanılmaktadır. Aks üzerindeki kesit değișim yerleri, özellikle aks ve tekerlek arasındaki geçiş bölgesi çatlamaya karşı çok daha zayıftır. Tüm bunlara ek olarak, dolu aksın toplam hacmi de güvenli kullanım şartları gereğince test edilmelidir.

Tahribatsız muayene yöntemlerinin önemli metodlarondan olan Ultrasonik muayene yöntemi malzemenin hacimsel olarak incelenebildiği, hataların türünün, boyutunun ve konumunun tespit edilebildiği bir yöntemdir.

Günümüzde ultrasonik muayene çoğunlukla darbe yankı tekniği ile gerçekleştirilir. Ses darbesi muayene parçasına gönderilir ve yansıyan darbe algılanır. Darbe, oluşum yerine geri dönerse bu cihaz üzerinde sinyal olarak tespit edilir. Operatör açısından önemli olan aldığı sinyalin gerçekten bir 
hatadan mı geldiği yoksa parça geometrisinden yada farklı yönlerden yansıyan ses dalgalarının oluşturduğu hayalet yankılar denilen ses dalgalarından alınan sinyaller mi olduğunun ayırt edilebilmesidir.

Phased array yöntemi de aynı prensipde çalışıyor olsa da, bu yöntemde gönderilen ses dalgalarının şeklini ve yönünü kontrol eden bilgisayar yazılımları kullanılarak hataların daha hassas belirlenmesini sağlayan dinamik odaklama ve gerçek zamanlı görüntüleme mümkün olmaktadır. Phased array propları birbirinden bağımsız olarak görev yapan çok sayıda elementten oluşur. Phased array yönteminin en önemli özelliği bu bağımsız elementlerin yazılım kontrolü ile uyarılmasıdır. $\mathrm{Bu}$ çalışmanın amacında aks üzerindeki tekerlek ve fren sistemi sökülmeden aksın tamamının muayene edilmesi esas alınmıştır. Bu amaçta aynı noktalan yapılan muayeneler ile konvensiyonel ultrasonik muayene ve phased array muayenesi sonuçları karşılaştırılmış ve incelenmiştir.

\subsection{Ultrasonik Muayenin Temel Prensibi}

Tahribatsız muayene konusunun dallarından biri olan ultrasonik muayene; malzemelerin analiz uygulamalarında geniş bir kullanım alanına sahip çok yönlü bir muayene yöntemidir. Ultrasonik muayene malzeme içerisindeki hataların ve hata bölgesinin yerinin tespit edilmesinde, ayrıca bunların akustik olarak ekrana aktarılmasıyla bu hataların değerlendirilmesinde, parçaların kalınlık ölçümünde kullanıldığı gibi, yüksek frekanslı ses dalgalarıyla katı ve sıvıların temel mekanik, yapısal ve bileşim özelliklerinin ölçümlerinde de kullanılabilir. Ultrasonik muayene cihazında kısa darbe süreli yüksek bir gerilim oluşturulur, bu gerilim probun kristalinde insan kulağının işitm sınırı dışında $>16.000 \mathrm{~Hz}$ 'lik bir mekanik salınıma neden olur. Bu salınım muayene parçasında ses dalgalı şeklinde yayılır. Ses dalgası sınır yüzeyden yansır ve aynı yolda kristle geri döner. Alınan ses dalgası cihaz ekranında görünür hale getirilir. Bu şekilde gönderilen darbe ve belirli bir ses mesafesindeki yansıtıcıdan alınan yankı ile cihazın doğru olarak ayarlanması mümkün olur. Konumlandırma için formül veya diğer yardımcılar kullanılarak muayene parçasındaki yansıtıcının yeri tespit edilebilir.

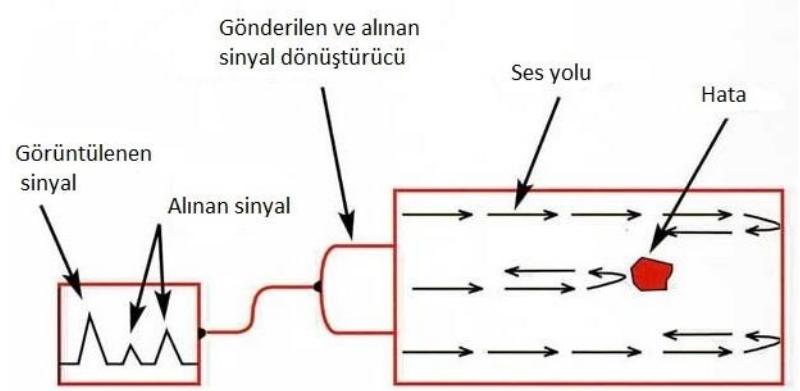

Şekil 1. Ultrasonik muayenede hata tespiti. 1.1.1 Dalga Tipleri
Ses malzemede boyuna ve enine dalgalar halinde yayılır. Boyuna dalga vakum hariç her ortamda, enine dalga ise katı ortamda yayılır. Sesin yayılma hızı (c) malzeme cinsine ve dalga tipine bağlıdır. Ses hızı ve frekans arasında aşağıdaki bağıntı mevcuttur;

$c=\frac{\lambda}{T}$

$c=\lambda \times \mathrm{f}$

Bu bağıntıda c; ses hızı (m/sn), f; frekans (1/sn), $\lambda$; dalga boyu (mm)'dur.

Ses dalgaları malzemeden geçerken tane sınırları ve safsızlıklar nedeniyle az veya çok zayıflarlar. Ses malzeme içerisinde bir ses demeti halinde ilerler, ses demetinde artan mesafe veya derinlik ile sesin basincında ya da şiddetinde hangi azalmanın olacağı mesafenin karesi kuralı ile açıklanır.

Kazanç değeri ve aynı zamanda ses zayıflaması bir oranla desibel olarak aşağıdaki bağıntılar ile verilir.

$\alpha=\frac{20 \cdot \log \left(A_{2} / \mathrm{A}_{1}\right)}{s_{2}-s_{1}}$

Burada A2 ve A1 sesin genliğini göstermektedir.

Ses mesafesi $s_{1}$ 'den $s_{2}{ }^{\prime} y e$ doğru değişirse ses genliğindeki zayıflama $(\alpha)$ aşağıdaki gibi belirlenir.

Örnek olarak genlik (yankı yüksekliği) yarıya düşerse $\mathrm{s}_{1}$ mesafesinden $\mathrm{s}_{2}$ mesafesine doğru ses zayıflaması $6 \mathrm{~dB}$ olur.

Ultrasonik muayenede temel olarak enine ve boyuna olmak üzere iki çeşit dalga tipi vardır.

Boyuna dalgalarda yayınım doğrultusu ile titreşim doğrultusu Şekil 2' de görüldüğü gibi aynıdır.

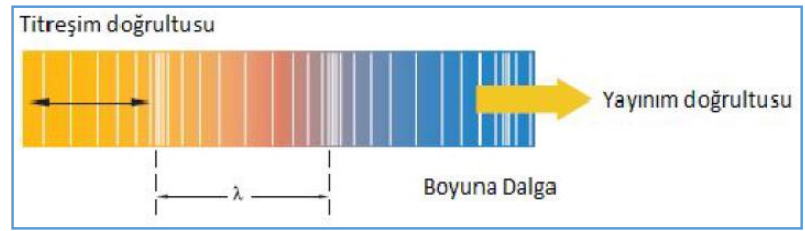

Şekil 2. Boyuna dalga.

Enine dalgalarda yayınım doğrultusu ile titreşim doğrultusu Şekil 3'de de görüldüğü gibi birbirine diktir.

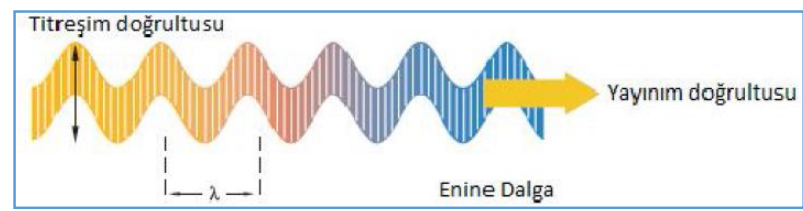

Şekil 3. Enine dalga.

Sınırlı yayılma ortamlarında enine ve boyuna dalgaların kombinasyonu olan Rayleigh Dalgası (Yüzey Dalgası), 
Lamp Dalgası (Platten Dalgası) gibi birçok dalga tipi de meydana gelir.

\subsubsection{Ultrasonik Muayene Yöntemi Bileşenleri}

Ultrasonik muayene cihazı, esas itibariyle duyarlı olarak zaman ölçen bir osiloskoptur. Darbe - yankı tipi bir ultrasonik cihazın blok diyagramı Şekil 4'de verilmiştir. Katot 1şını tüpü (CRT veya ekran), tarama devresi, darbe devresi, algılama-yükseltme devresi, zaman devresi ve prob bir ultrasonik cihazın temel elemanlarını oluşturmaktadırlar.

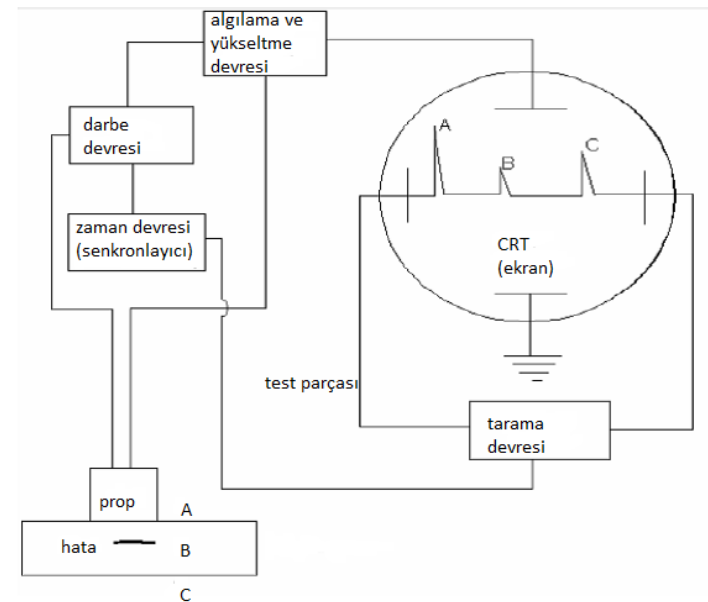

Şekil 4. Ultrasonik muayene cihazının şematik gösterimi.

Dalga üretiminde piezoelektrik olayından faydalanılır. Piezoelekrik malzemesine dış etki ile basınç uygulanılarak deforme edilirse yüzeylerinde elektriksel yük oluşur. Eğer basınç kuvvetinin yönü değiştirilerek çekme kuvveti uygulanırsa yüzeylerdeki elektrik yüklerinin işareti değişir. $\mathrm{Bu}$ olay tersinirdir ve piezoelektrik elemanın iki yüzeyine elektrod yerleştirilerek elektrik yükü uygulanırsa kristalin şekli değişir. Kristale uygulanan elektrik yükü sürekli değiştirilirse piezolektrik malzemede titreşim oluşturulur. Elektrik yükü ile mekanik basınç birbirleri ile orantılıdır. Piezoelektrik özelliğe sahip birçok malzeme bulunmaktadır. En çok kuvars ve lityum sülfat gibi doğal malzemeler ve baryum titanat ve polisitalin keramik gibi yapay malzemeler kullanılır.

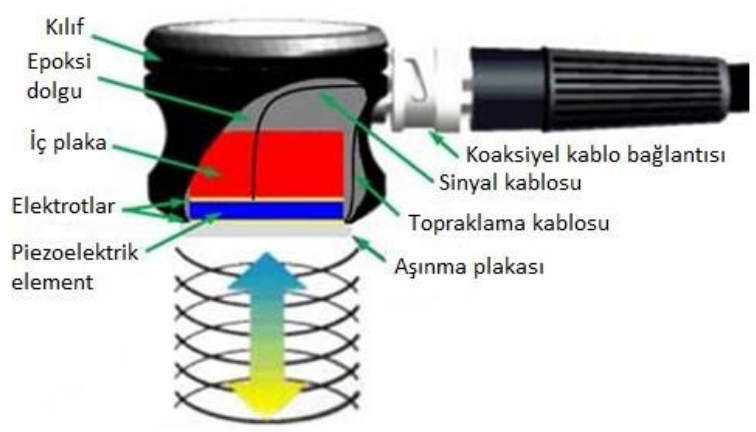

\subsubsection{Ultrasonik Muayenenin Uygulanması}

Ultrasonik muayenede uygulanan teknikler üç parametre dikkate alınarak sınıflandırılabilir. Bunlar; ölçülmek istenen fiziksel büyüklük (genlik, faz, zaman), ses üretim şekli (sürekli, darbe) ve süreksizliklerin etki şekli (yansıtıcı, gölgeleyici, ses üretici) olarak yapılabilir. Muayene tekniği bu parametreler göz önüne alınarak seçilir [2].

Darbe yankı yöntemi, Malzemelerin ultrasonik muayenesinde en çok kullanılan yöntemdir. Bu yöntem, prob tarafından yayılan ses dalgalarının malzeme içindeki süreksizliğe çarpıp geri yansıyarak tekrar proba ulaşması esasına dayanır. $\mathrm{Bu}$ yöntemde ölçülen büyüklükler ses basıncı genliği ve darbenin girdap dönüş süresi olup süreksizlik bir yansıtıcı olarak etki eder.

$\mathrm{Bu}$ çalışmada da demiryolu aksı ultrasonik muayenesinde darbe yankı yöntemi uygulanmıştır.

\subsection{Phased Array Yöntemi Uygulama Prensibi}

Phased array tekniğinde gönderilen ses dalgalarının şeklini ve yönünü kontrol eden bilgisayar yazılımları kullanılarak hataların başlangıç ve bitiş noktalarının daha hassas belirlenmesini sağlayan dinamik odaklanma ve gerçek zamanlı görüntüleme mümkün olmaktadır [3].

Hataların tespit edilmesi ve analiz edilmesi için kural olarak farklı ancak belirli ses alanı özelliklerine (normal, açılı, odaklayıcı) sahip bir çok probun kullanılması gerekir. Gerekli prop sayısı test edilecek parçanın geometrisine, olası malzeme hatalarının konum ve yönlenmelerine ve muayene parçasına yaklaşılabilirlik durumuna bağlıdır. Phased Array tekniği phased array problarındaki her bir elementin elektronik olarak uygun bir şekilde yönlenmesiyle ses alanına etki edilerek bir çok klasik propla yerine getirilebilecek fonksiyonların sağlanmasını mümkün hale getirir.

\subsubsection{Elektronik Ses Alanı Yönetim Prensibi}

Phased array probları birçok elementten oluşan ultrasonik kristale sahiptir, bu şekilde her element ayrı ayrı ultrasonik dalga gönderebilir ve alabilir. Bunun için her element bir elektronik yapı grubuna bağlanmıştır, bu bağlantı gönderici durumunda elementin programlanabilen gecikme süresiyle uyarılmasını sağlar.

Phased array tekniği probundaki elementin yönetimiyle uygun gecikme süresinin ayarlanmasıyla ses alanı salınır veya odaklanır. $\mathrm{Bu}$ salınım lineer gecikme süresiyle odaklama ise simetrik kare şeklinde quadratic gecikmeyle gerçekleştirilir. Lineer ve kare şeklinde gecikmelerin üst üste binmesiyle ses alanı aynı anda salınır ve odaklanır (Şekil 6).

Şekil 5. Tek kristalli normal bir probun yapısı. 


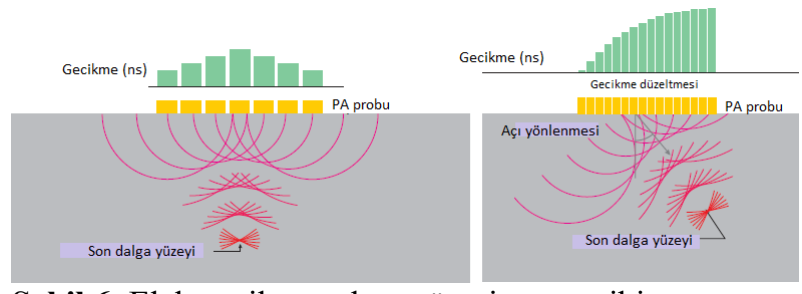

Şekil 6. Elektronik ses alanı yönetim prensibi.

Alic1 durumunda malzemeden geri gelen ultrasonik sinyalleri kristal elementlerine farklı zamanlarda ulaşır. Her element için alma sinyali dijitalleştirilir ve sonunda her elementin gecike süresi verici durumunda denkleştirilir. Sinyal işlenmesinin son aşamasında zaman düzeltmesi yapılmış sinyaller ilave edilir.

\subsubsection{Phased Array Yönteminde Tarama Teknikleri}

Malzeme içindeki hata ve süreksizliklerin güvenilir şekilde belirlenmesi uygulanan tarama modeli ve uygun bir prob seçimine bağlıdır. Muayene otomatik, yarı- otomatik veya manuel olarak uygulanabilir. Otomatik uygulamada prob motorla kontrol edilen bir taşıyıcı üzerindedir, yarı-otomatik uygulamada prob elle kontrol edilen bir taşıyıcıya bağlanmıştır, manuel uygulamada ise probun elle hareket ettirilmesiyle muayene gerçekleştirilir. Probun hareket ettirilme şekline göre farklı tarama yöntemleri bulunmaktadır. Otomatik ve yarı-otomatik uygulamalarda kullanılan başlıca tarama yöntemleri aşağıdaki gibi siralanabilir [4].

Lineer tarama tek eksen üzerinde probun hareket ettirilmesiyle gerçekleştirilir. Genelde kaynak bölgelerinin incelenmesi ve korozyon haritalandırılmasında kullanılır. Satır satır taramada probun adım adım hareket ettirilmesi gerekirken lineer taramada ise aynı bölge çok fazla sayıda piezoelektrik elemana sahip olan prob ile taranması sayesinde tek eksen üzerinden hareketle ve adım adım taramaya göre çok daha hızlı olarak gerçekleştirilmektedir.

Sektörel tarama ses dalgasının belirlenen açı aralığında ve belirlenen açı adımlarında farklı darbe zamanlarıyla salınım yaparak bir alanı tarama yöntemidir. Genellikle dolu malzemelerde hacım taramalarında kullanılır.

\subsubsection{Phased Array Yönteminde Görüntüleme Teknikleri}

Ultrasonik dalgalarla elde edilen görüntüler tarama parametrelerine göre dalganın aldığ 1 yol tarafindan belirlenir. En çok kullanılan görüntüleme teknikleri dalgaların malzeme üzerindeki davranışlarının iki boyutlu olarak ekrana aktarılmasıyla elde edilen B, C ve D ekran teknikleridir. Şekil 7'de görüldüğü gibi bu ekranlar muayene parçasının önden (D-ekran), yandan (B-ekran) ve üstten (Cekran) görüntüsünün cihaz ekranı üzerinde iki boyutlu olarak görüntüsüdür. B ve Dekranlarda parça içindeki hatanın konumuna göre derinliği belirlenebilir [5].

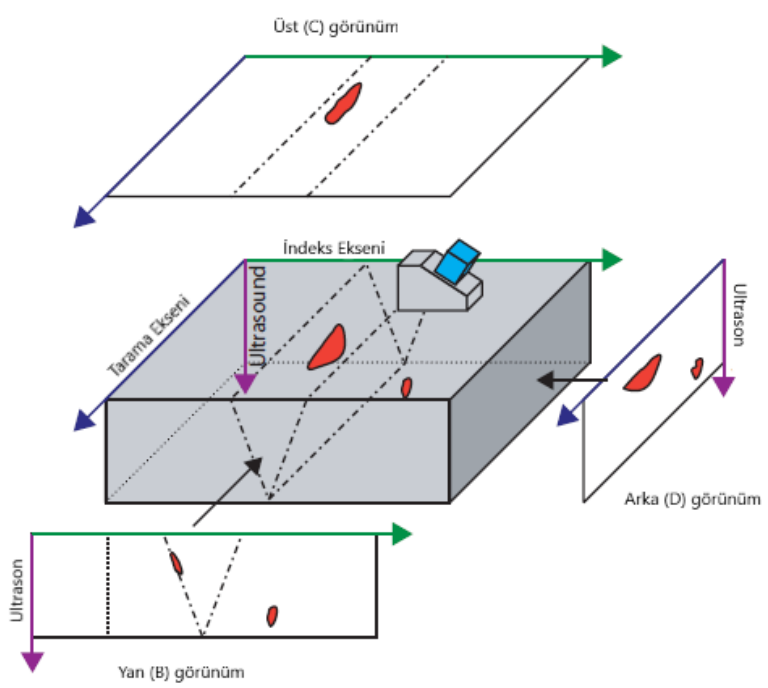

Şekil 7. Phased array görüntülerinin parça üzerindeki karşılıkları.

Phased array yönteminde konvansiyonel ultrasonik muayenenin temelini oluşturan A-ekran da kullanılır. Aekran gönderilen ultrasonik dalganın büyüklüğünü ve aldığı yolu gösteren bir frekans grafiği şeklinde görülen ekrandır. Burada dönen yankının büyüklüğüne göre ekran üzerinde gelen yankı dalgaları görülür ve buradan malzeme içindeki hata büyüklüğü ve konumu hakkında yorum yapılabilir. Yankı genliği dikey eksende, dalga geçiş zamanı da yatay eksende yer almaktadır.

Bunların dişında phased array yönteminde S-ekran ve polar görüntü teknikleri de kullanılmaktadır. S-ekran tekniği, Şekil 8'de görüldüğü gibi sektörel veya belli istikamet açısındaki tüm A-ekran görüntülerinin iki boyutlu olarak görüntülenmesidir. Probun hareket ettirilmeden kristal dizisi boyunca elektronik tarama ile malzemenin kesitsel görüntüsü çıkarılabilir. Ardı ardına kristaller önceden belirlenmiş gruplar halinde etkin hale getirilir ve probdaki tüm kristallerin kapladığ $\breve{1}_{\text {alan }}$ boyunca doğrusal tarama yapılır. Prob hareket ettiriliyormuş gibi gerçek zamanlı olarak taranan bölgenin kesitsel görüntüsü alınabilir. Bu yöntem özellikle otomatik olarak yapılan kaynak muayenesinde oldukça kullanışlıdır. Taban bloğu veya takozu takılan prob belirlenen açılarda enine dalgalar oluşturabilir ve tarama esnasında probun kaynak dikişinden uzaklaştırılmasına gerek kalmadan aynı eksen üzerinde hareketiyle kaynak bölgesinin verileri alınabilir. Polar görüntü ise boru gibi silindirik parçaların iki boyutlu olarak görüntülerinin alınmasıdır. 

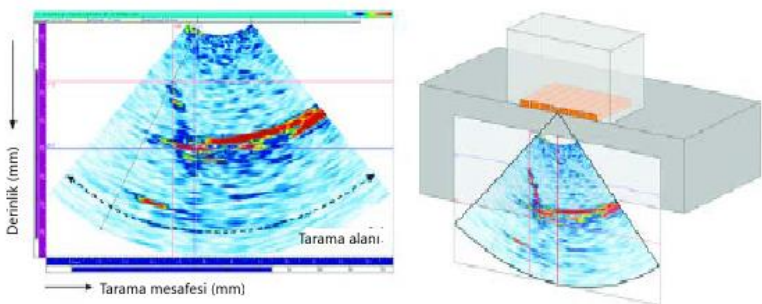

Şekil 8. S-ekran görüntüsü.

\subsubsection{Phased Array Yönteminde Kullanılan Prop Çeşitleri}

Piezokompozit malzemelerin geliştirilmesi ve mikro işleme teknolojisindeki gelişmelerle beraber çok farklı yapıda probların üretimi imkanlı hale gelmiştir. Prob seçiminde, muayene yapılacak bölgeye gönderilecek dalgaların özellikleri, kontrol edilecek bölgenin derinliği ile probun kullanılacağı bölgeyle olan açısal konumu, muayene yapılacak parçanın yüzey durumu gibi faktörler dikkate alınır. Genelde lineer problar muayene yapılacak bölgeye prob takozu denilen özel parçalarla tespit edilir. Bu takozlarla gönderilen dalgaların istenilen açıda ve erteleme süresinde gönderilmesi sağlandığı gibi farklı bölgelerde aynı probun kullanılmasını, örneğin farklı boru çaplarında farklı içbükey yarıçapına sahip takozların yardımıyla, imkanlı hale getirir. Phased array yönteminde kullanılan temel prob çeşitleri Şekil 9'da görülmektedir.

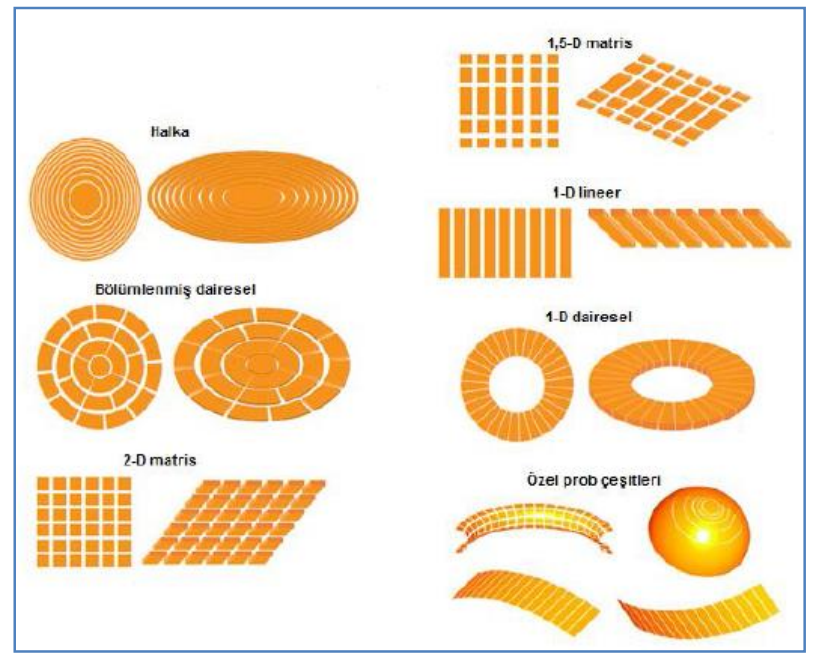

Şekil 9. Phased array prob çeşitleri

Bölümlenmiş dairesel ve halka yapısındaki problar iç içe konumlandırılmış kristallerden oluşmaktadır. Bu problarla ses demeti eksenine göre simetrik bir ses basincı oluşturulabilir ve parça içerisinde istenen noktaya odaklanma sağlanabilir. Lineer veya başka bir deyişle doğrusal sıralı problar ise en yaygın olarak kullanılan prob tipidir. Bunun en büyük nedeni bu probların programlanmaları ve malzeme içerisine gönderilen ses demetinin kontrol edilmesinin diğer prob tiplerine göre daha kolay olmasıdır. Bu problarda kristaller doğrusal olarak yerleştirilmişlerdir. Boyuna, enine ve yüzey dalgası üretilmesi mümkündür.
Matris şeklinde dizilmiş düzlemsel dizilimli problar lineer problara göre daha hassas bir odaklanma imkânına sahiptir. Ancak bu probların imalat zorluğundan kaynaklanan yüksek maliyeti ve programlamasının daha zor olmasından dolayı kullanımı lineer problara göre daha azdır

\section{MALZEME VE YÖNTEM}

Deneysel çalışmalar; tren aksları üzerinde veya içerisinde gözle görülemeyen hata veya süreksizlikleri tespit edebilmek için ultrasonik yöntem ve Phased array yönteminin uygulanmasını kapsamaktadır.

Konvensiyonel ultrasonik muayene ve phasedarray yönteminin hataların tespit edilmesi ve ayırt edilebilirliği yönünden karşılaştırılması amacıyla aks üzerinde farklı çap ve mesafe bölgelerinde $3 \mathrm{~mm}$ derinliğinde çentikler açılarak suni hatalar oluşturulmuştur.

Şekil 10, 11, ve 12'de deney düzenekleri görülmektedir.

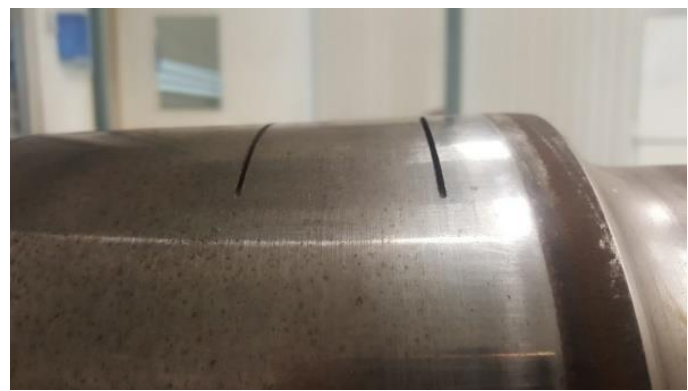

Şekil 10. Aks üzerinde oluşturulan $3 \mathrm{~mm}$ derinliğindeki hatalar.

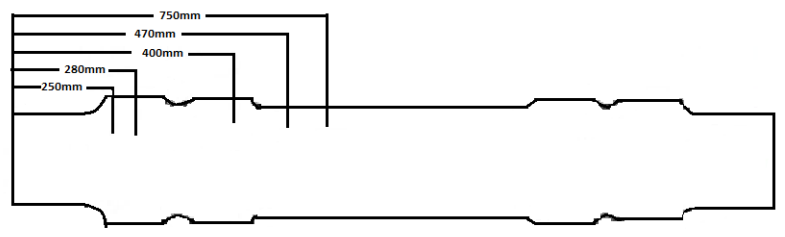

Şekil 11. Aks üzerinde hataların konumları.

Muayene aksın her iki yan yüzeyinde prop $360^{\circ}$ çevresel olarak döndürülerek gerçekleştirilmiştir.

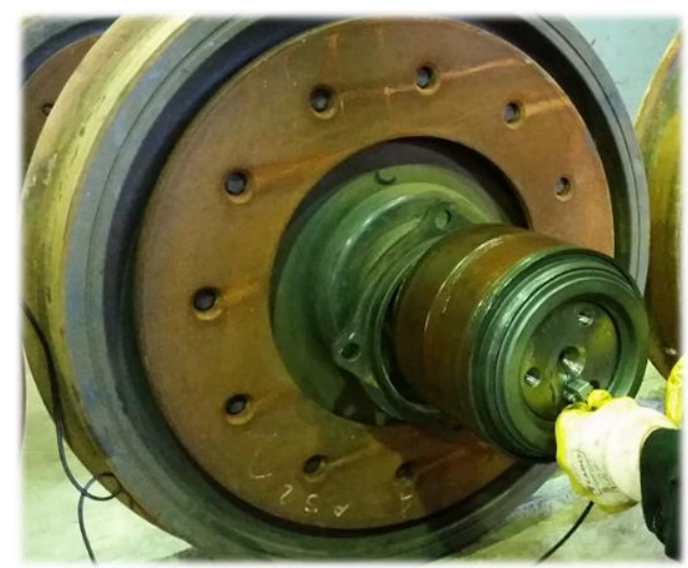

Şekil 12. Aksın muayene edilmesi. 


\section{BULGULAR}

\subsection{Ultrasonik Muayene Yöntemi İle Aks Muayenesi}

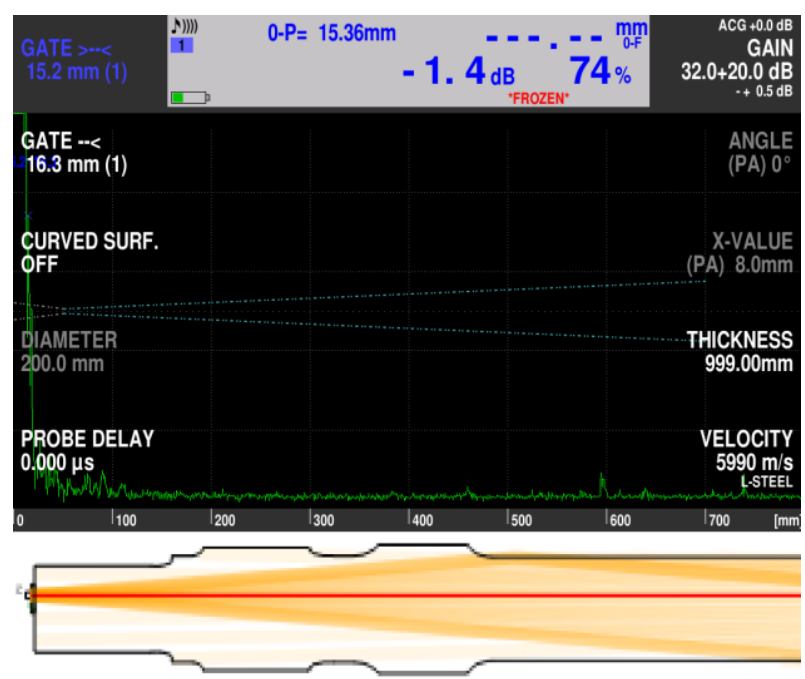

Şekil 13. $0^{\circ}$ prop ile ultrasonik muayene görüntüsü ve şematik gösterimi.

$0^{\circ}$ prop ile ultrasonik muayenede muayene parçasında ultrasonik ses dalgası çıkış noktasından itibaren herhangi bir hata veya geometrik yansitıcıya çarpmadığından dolayı arka cidara doğru ilerleyerek parça içerisinde sönümlenmektedir (Şekil 13). Şematik görünüm üzerinde incelendiğinde 450 mm uzaklıkta ufak bir geometrik sinyal görünmektedir. Bundan sonra $600 \mathrm{~mm}$ uzaklıkta alınan sinyal hayalet yankı denilen parça içerisindeki ultrasonik ses dalgalarının yansıyarak oluşturduğu sinyaldir.

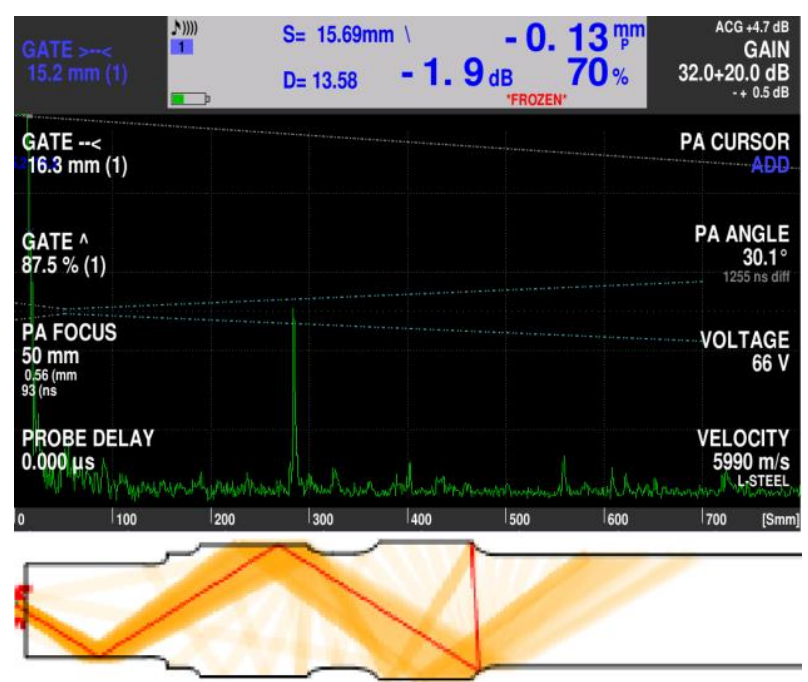

Şekil 24. $30^{\circ}$ prop ile ultrasonik muayene görüntüsü ve şematik gösterimi.

Şekil $14^{\prime}$ 'de $30^{\circ}$ ultrasonik prop ile aks muayenesinde ultrasonik ses dalgası şematik olarak görülebileceği gibi yaklaşık $100 \mathrm{~mm}$ mesafeden yansıyarak $280 \mathrm{~mm}$ hatanın olduğu bölüme geldiği için bu hata net olarak görülebilmekte ancak yanında olan $250 \mathrm{~mm}$ de ki hatadan ultrasonik ses demeti çapının dışında kalmasından dolayı sinyal alınamamıştır. Bunun dişında kalan sinyaller parça geometrisi ve ses dalgasının açılı gönderilerek farklı bölgelerden yansıması nedeniyle parazit olarak görülmektedir.

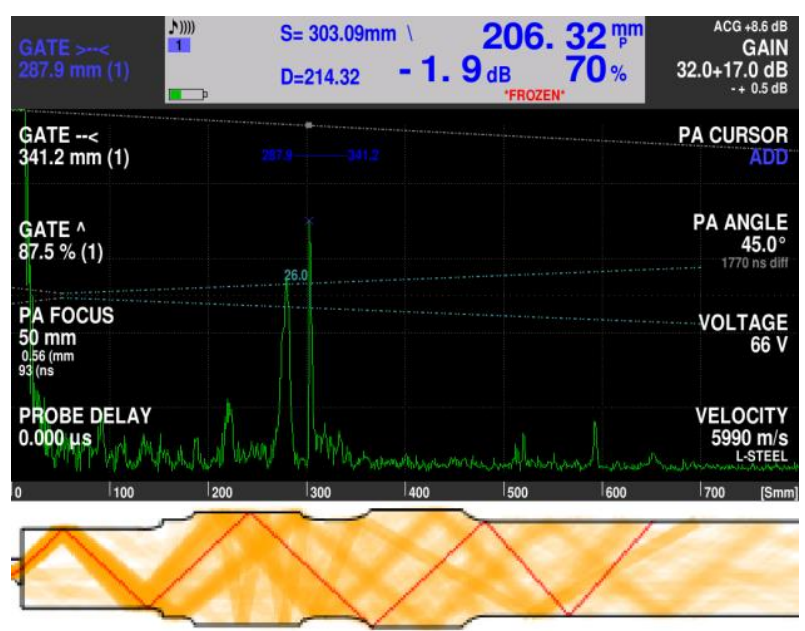

Şekil 35. $45^{\circ}$ prop ile ultrasonik muayene görüntüsü ve şematik gösterimi.

Şekil $15^{\prime}$ de verilmekte olan $45^{\circ}$ prop ile ultrasonik muayenede ses dalgası yaklaşı $50 \mathrm{~mm}$ ve $130 \mathrm{~mm}$ çift sekmede yansıyarak $250 \mathrm{~mm}$ ve $280 \mathrm{~mm}$ uzaklıktaki iki hatanın olduğu bölgede $280 \mathrm{~mm}$ deki hatadan daha yüksek sinyal almak kaydiyla iki hata da tespit edilebilmiştir. Bununla beraber $300 \mathrm{~mm}$ uzaklıkta aks geometrisinden kaynaklanan sinyalde görülebilmektedir. Sonraki hataların ultrasonik dalganın aks içerisinde birçok yerden yansıması sebebiyle hayalet yankılar ve parazitler arasında ayırt edilmesi mümkün olmamaktadır.

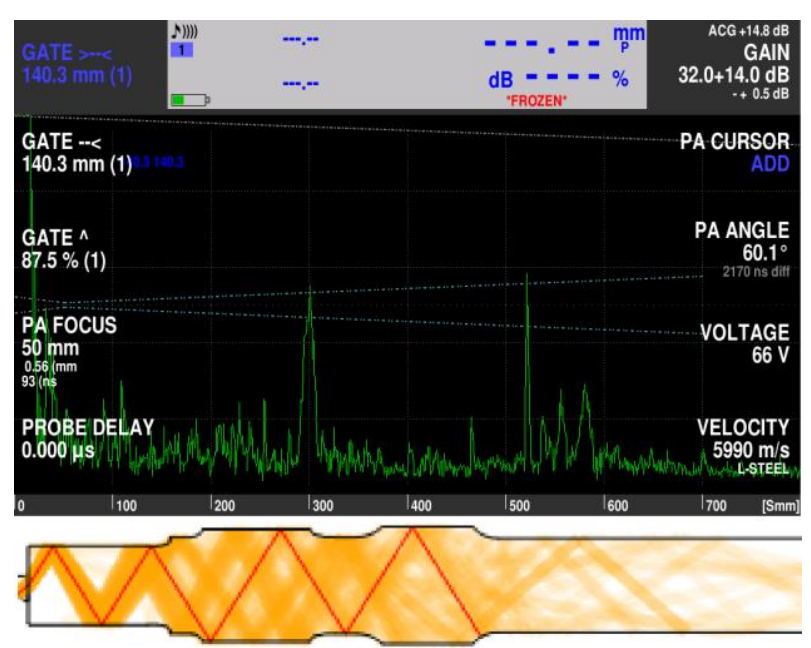

Şekil 46. $60^{\circ}$ prop ile ultrasonik muayene görüntüsü ve şematik gösterimi.

Şekil $16^{\prime}$ da $60^{\circ}$ prop ile ultrasonik muayenede ultrasonik ses dalgası parça geometrisine göre birçok bölgeden 
yansıdığından dolayı çok fazla hayalet yankı ve parazit oluşmaktadır. $300 \mathrm{~mm}$ uzaklıktaki parça geometrisinden gelen sinyal baskın olarak görülmekte ancak hata sinyallerinin bu parazitler arasından ayırt edilmesi mümkün olmamaktadır. Muayene parçasının doğal sınırları (arka cidar, kenar) ses dalgasını parça içerisindeki hata gibi yansitır ve darbe süreleri veya ses yolları ile hata bulgusundan ayırt edilebilir. Bu ayrım çoğu kez ilave prop pozisyonu ile yapılabilir. Düzlem veya dik açılı yüzeylerden ses çok iyi yansımaz. Bazı geliş açılarında örneğin yaklaşık $60^{\circ}$ enine dalga geliş açısında, köşe etkisi meydana gelmez, neredeyse tamamı çıkış noktasına geri dönmeyen ve gelen ses dalgasına dik boyuna dalgaya dönüşür

\subsection{Phased Array Yöntemi Ile Aks Muayenesi}

Muayene TD Handy Scan RX Phased Array muayene cihazı ile gerçekleştirilmiştir. Tarama probu olarak 16 elementli Olympus 5L16A-1 probu kullanılmıştır. Şekil 17'de görüldüğü üzere her farklı çap bölgesinde sektörel tarama ile ses demeti odaklanarak aksın toplam hacminin muayene edilmesi amaçlanmıştır. Tarama bölgelerini belirleme çalışmasında S-Beam Tools yazılımı kullanılmıştır.

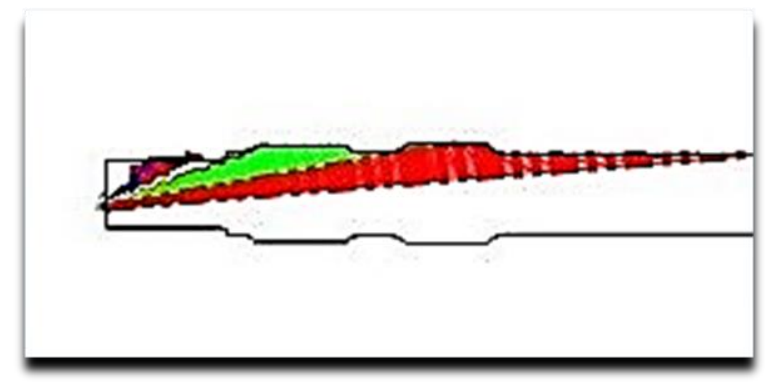

Şekil 57. Phased array tarama bölgeleri.

Muayene sonrası test raporu Şekil 18'de gösterilmiştir. Aks üzerinde $250 \mathrm{~mm}, 280 \mathrm{~mm}, 400 \mathrm{~mm}, 470 \mathrm{~mm}$ ve $750 \mathrm{~mm}$ mesafelerinde oluşturulmuş olan hatalar test raporunda görülebilmektedir.

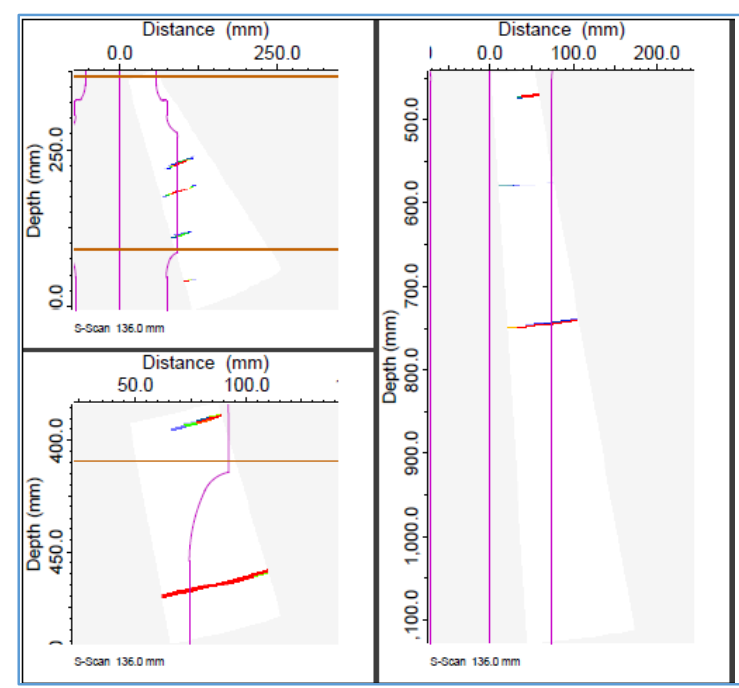

Şekil 186. PhasedArray muayenesi test raporu.

\section{DEĞERLENDİRME VE SONUÇ}

$\mathrm{Bu}$ çalışmada üstün özelliklere sahih ve yaygın olarak kullanılan geleneksek ultrasonik metod ile yeni ve daha gelişmiş bir metdo olan phase array yöntemi karşılaştırılmıştır. Her iki yöntemde hacimsel hataların tespitinde kullanılmaktadır.

Konvansiyonel ultrasonik muayenede monokristal bir prob kullanılarak dalgalar gönderilir. Bazı durumlarda ise hem alıcı hem verici görevini ayrı elemanlarla yapan çift elemanlı problar kullanılır. Ancak phased array yönteminde kullanılan problar birbirinden bağımsız olarak görev yapan çok sayıda elemandan oluşur. Bu eleman sayısı 16'dan 256'ya kadar ulaşabilmektedir. Endüstride genellikle çalışmamızda da kullandığımız 16 elementli proplar kullanılır. Muayene duyarlılığını arttırmak için element sayısı yüksek olan proplar kullanılabilir ancak yüksek maliyetler sebebiyle çok tercih edilmez.

Phased array yönteminde elementlerin farklı zamanlarda ateşlenmesiyle sağlanan lineer tarama ve sektörel taramada dinamik odaklama kabiliyeti sayesinde özellikle büyük parçalarda meydana gelen konvensiyonel ultrasonik muayenedeki ses demetinin açınım açısından kaynaklanan sesin dağılmasının önüne geçilmiştir.

Phased array yönteminin tek prop ile çok açılı ses dalgası uygulanabilmesi, ses demeti yönünde ve tarama yönünde mesafe kaydı işlenmiş veri ile üç boyutlu değerlendirme olanağı, kolay hata bulma ve geniş raporlama özelliği ile operatöre bağımlılık azalmaktadır. Farklı ses demetleri oluşturarak odaklama yeteneği ile konvensiyonel ultrasonik muayenede oluşan özellikle büyük parçaların muayenesinde ses demetinin dağılması sebebiyle hatanın tespit edilememesi gibi problemlerin önüne geçilmiştir. Prop sistemlerinin boyutlarının küçük olması kısıtlı muayene yüzeylerinde yüksek hassasiyet sağlamaktadır.

Phased array yönteminin konvensiyonel ultrasonik muayeneye nazaran dezavantajları ise ekipmanlar ve yedek parçaların yüksek maliyette olması, kalibrasyonun karmaşık ve zaman alıcı olmasıdır. $\mathrm{Bu}$ sebeplerden ötürü iyi ve donanımlı operatörlere gereksinim vardır.

\section{KAYNAKÇA}

[1]VECTOR Technische Unternehmensberaung $\mathrm{GmbH}$, Hattingen 2001

[2]Uçaklarda Tahribatsız Muayene, Milli Eğitim Bakanlığı, Ankara, 2012

[3] GUR, C., Tahribatsız muayene personelinin ASNT sistemine göre eğitimi ve belgelendirilmesi, ASNT Türkiye Birimi, Ankara, 2008

[4]SECTOR Cert Gesellschaft für Zertifizierung $\mathrm{mbH}$, Automatishe Ultraschallprüfung, 2009

[5] OLYMPUS, Advances in Phased Array Ultrasonic Technology Applications, Olympus NDT Inc., MA, 2007 